\title{
A Pillar For Successful Business School Accreditation: Conducting The Curriculum Review Process - A Systematic Approach
}

\author{
David E. Gundersen, Stephen F. Austin State University, USA \\ Susan Evans Jennings, Stephen F. Austin State University, USA \\ Deborah Dunn, Stephen F. Austin State University, USA \\ Warren Fisher, Stephen F. Austin State University, USA \\ Mikhail Kouliavtsev, Stephen F. Austin State University, USA \\ Violet Rogers, Stephen F. Austin State University, USA
}

\begin{abstract}
The Association to Advance Collegiate Schools of Business (AACSB) describes their accreditation as the "hallmark of business education." According to information at BestBizSchools.com (n.d.), "AACSB accreditation represents the highest standard of achievement for business schools worldwide. Being AACSB accredited means a business school is able to continuously pass a strict set of standards that ensure quality." As of December 2010, only 5\%, or 607, of the academic business programs globally were accredited by AACSB. This number represents schools in 38 countries where the majority of programs incorporate both undergraduate and graduate education covering business, accounting, or both. An institution must be a member of AACSB in order to apply for accreditation. It is important to note, however, that membership does not imply that the program is accredited (The Association to Advance Collegiate Schools of Business, n.d.a). Recent emphasis demanding external validation on the quality of "Business Schools" has resulted in the promotion of AACSB accreditation as the de facto quality standard. Earning this quality seal of approval, business programs can verify they have met the 21 AACSB standards that cover strategic, participant, and assurance of learning achievements and processes. Programs with AACSB accreditation are encouraged to promote the standard using it to externally validate their quality and to market their programs to external groups including students, employers, and contributors (The Association to Advance Collegiate Schools of Business, n.d.-b). Despite established standards, no single approach to meeting standards for accreditation is suggested by $A A C S B$. Rather, varying approaches to meeting standards should be developed to fit individual programs of institutions (Bryant \& Scherer, 2009). This position by AACSB underscores its recognition of the diversity across accredited programs and allows educators wide latitude in developing and implementing approaches to excellence. Small programs are not disadvantaged so long as their students, faculty, graduates, and the employers who hire them receive the quality outputs that help them meet the external competitive requirements (Olian, 2007). In recognition of member institutions' diversity, the AACSB has established the Affinity Group program where school administrators from schools sharing similar characteristics can interact, exchange ideas, and present views on a wide range of issues (Olian, 2007). This allows AACSB member schools, who have varying missions and constituents, to find and link with other programs of a similar nature where creativity and synergy can more easily occur. The AACSB wants the accreditation process to help facilitate creativity in designing business school strategies rather than being viewed as an impediment to a program's push to quality (Romero, 2008).
\end{abstract}

Keywords: Accreditation, AACSB, curriculum, business core 


\section{THE CURRICULA MANAGEMENT STANDARD}

๑)

ne significant standard (Standard 15) addresses the management of curricula, which ensures that students receive the appropriate content in their respective programs. The standard, while not requiring a specific list of courses, does necessitate that each institution follow a systematic process that should be monitored on an ongoing basis and validated externally. This process should incorporate all aspects of curriculum management from the development of courses and programs through continuous improvement and evaluation. The AACSB views curriculum management as a required faculty responsibility needing more than occasional input (The Association to Advance Collegiate Schools of Business, n.d.-c). Despite being a faculty responsibility, internal perspectives incorporating only faculty opinions should not be the mainstay of curriculum review. External validation is required, needing inputs from a variety of sources from external constituents and sources. Faculty are charged with managing the system and should decide how best to ensure topics are presented and learned (Cann \& Brumagim, 2008; Weldy, Spake, \& Sneath, 2008).

Despite generalized commentary in the literature on curricula management (Athavale, David, \& Myring, 2008; Sampson \& Betters-Reed, 2008), no step-by-step processes are evident in meeting the required standard. This is probably due to the notion that variations in programs and institutions preclude cookbook accreditation processes despite the need and push for external validation. Consequently, approaches to acceptable curricula management within certain constraints are only limited by involved faculty and the creativity they bring to the task. The primary constraint is ensuring that required content topics are present in the program as required by Standard 15, Curricula Management. This standard is one of seven "Assurance of Learning" standards according to the AACSB (n.d.-b), which proclaims "The school uses well documented, systematic processes to develop, monitor, evaluate, and revise the substance and delivery of the curricula of degree programs and to assess the impact of the curricula on learning. Curriculum management includes inputs from all appropriate constituencies which may include faculty, staff, administrators, students, faculty from non-business disciplines, alumni, and the business community served by the school." In addition to the above statement, established content topics are mandated for incorporation into the core of the business program. The core comprises courses all students complete despite their designated majors in the business program. The list of content topics can be found in Table 1.

Student exposure to this content is not by itself sufficient for meeting accreditation requirements. It is rather the beginning that identifies topics students are required to master. Additional assurance of learning processes must be developed and deployed to ensure student mastery. Standard 15 becomes the foundation of what this learning should encompass.

Table 1. AACSB Curriculum Content Topics

\begin{tabular}{|l|l|}
\hline 1. & Communication abilities \\
\hline 2. & Ethical understanding and reasoning abilities \\
\hline 3. & Analytical skills \\
\hline 4. & Use of information technology \\
\hline 5. & Dynamics of the global economy \\
\hline 6. & Multicultural and diversity understanding \\
\hline 7. & Reflective thinking skills \\
\hline 8. & Ethical and legal responsibilities in organizations and society \\
\hline 9. & Financial theories, analysis, reporting, and markets \\
\hline 10. & Creation of value through integrated production and distribution of goods, services, and information \\
\hline 11. & Group and individual dynamics in organizations \\
\hline 12. & Statistical data analysis and management science as they support decision-making processes throughout an organization \\
\hline 13. & $\begin{array}{l}\text { Information technologies as they influence the structure and processes of organizations and economies, and as they } \\
\text { influence the roles and techniques of management }\end{array}$ \\
\hline 14. & Domestic and global economic environments of organizations \\
\hline
\end{tabular}

(The Association to Advance Collegiate Schools of Business, n.d.-b)

Regardless of the approach used to review curricula, these content standards must be present creating the foundation of the program that ensures a quality education. 


\section{A FRAMEWORK FOR CURRICULUM REVIEW}

The daunting task of ensuring curricula management can be organized into a framework that simplifies the process for those seeking accreditation or reaccreditation. This curricula management framework encompasses major components, which must be incorporated in the curriculum review process. These components will be briefly presented followed by a more detailed institutional example. The framework can be seen in Figure 1.

Curriculum content topics, as provided by the AACSB (see Table 1), provide the foundation for externally validating the content of the business program. All other components of the framework are predicated on acknowledging that these topics are in the curriculum of a given program. External stakeholder groups must have the opportunity to be aware of the content topics. This awareness allows feedback from these groups to a given business program.

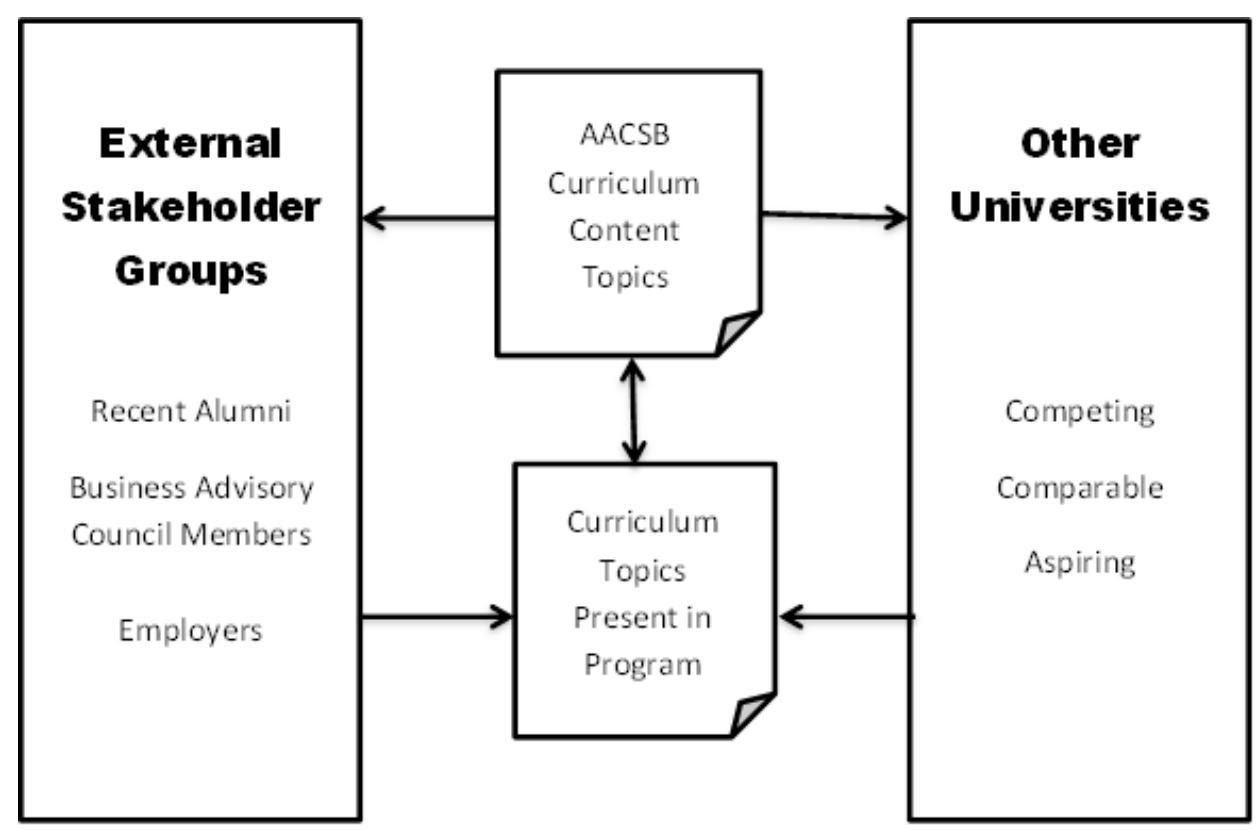

Figure 1. Curriculum Review Process Framework

Feedback can include, but not be limited to, rating the content quality in the program, commenting on unique aspects of the content, relating the importance of the content to the stakeholders, and showing how stakeholders benefit from the content's presence in the given program. These inputs provide faculty charged with managing the curriculum process information to validate their internal opinions as well as adjust how the content is delivered to improve benefits to the stakeholders. These stakeholders have a vested interest in the success of the program because they all benefit from improved quality. Examples of external stakeholders identified in the framework include recent graduates, business advisory council members if they exist, and employers who hire the graduates.

Another source of external information comes from other educational institutions. These institutions need to be examined with results documented and analyzed as they relate to the content standards. This documentation provides data that can be used for comparative, benchmarking, and diagnostic purposes. To provide greater insight it may be beneficial to divide institutions into similar groups. These groups could include direct competitors, similar schools that are not geographically competitive, and those that are considered higher tier with more name recognition and a stronger reputation. This grouping may reveal whether certain types of programs address content differently. Reviewing other business programs also allows comparisons regarding program length in terms of required semester hours. 
The final component of the framework is to analyze the current program using the information provided by stakeholders and comparative date from other educational institutions. From a diagnostic perspective, adjustments to the program can now be made. A variety of questions must be addressed with some examples as follows:

- Is the AACSB required content apparent in the program courses?

- $\quad$ Does the content need to be offered differently?

- Is there enough of each content topic in the courses?

- $\quad$ How could course content be improved to benefit external stakeholders?

- Should content be offered in a similar or dissimilar fashion compared to other institutions?

\section{PROCESS EXAMPLE}

The following example provides business programs with a model of how the curriculum framework can be applied to an individual accreditation or reaccreditation effort. The components of the model are discussed in detail where needed individual decisions for institutions can be identified for deliberation.

\section{The Faculty Team}

The decision to obtain initial AACSB accreditation or to receive reaccreditation is most often the responsibility of administration. University administration should be cognizant of the impact on salaries and research productivity. Faculty in accredited programs are paid more, teach less, and publish more than their counterparts at non-accredited programs (Hedrick, Henson, Krieg, \& Wassell, 2010). Assuming support is provided above the business academic unit by a Provost or Vice President, the head of the business unit, usually a Dean, forms a faculty committee to be responsible for curriculum management. If the academic business unit contains multiple functional departments (i.e. Management Department), the Dean selects representatives from each department. If the academic business unit is not departmentalized, each functional area within the unit should be represented. Significant service credit is typically bestowed on individual faculty selected for the team (Shao \& Anderson, 2009).

The faculty team should be comprised of members with significant diversity in respect to their educational backgrounds, including their degrees and the institutions that granted them. Diversity should also be reflected in faculty experiences that provide more depth of expertise to bring to the curriculum management task. It is essential that selected members of the committee have extensive knowledge of the curriculum in their respective discipline course offerings. This frequently requires senior members of the academic unit to be represented on the committee. Members representing each area provide a knowledge base for identifying where the required content topics (Table 1) are present in the current curriculum and allow linking topics to the core courses offered in the program. Because these content topics must be represented in the curriculum, after this analysis, any adjustments needed should be noted and documented for future use by the team.

\section{Other Universities}

External sources of information are needed to validate the curricula of a particular program. One source of information used to enhance external validity is to compare and benchmark the curriculum under review to that of other institutions. While no set number is established for comparative purposes, benchmarking to a variety of schools provides more in depth data for benchmarking purposes. Consequently, selection of other programs must follow careful considerations ensuring a good range of matching potential (Bryant \& Scherer, 2009). It is possible that a particular program matches content topics differently than similarly characterized institutions. Regional universities may match certain content topics in ways more similar to national institutions or vice versa. Certain business functional areas, because of faculty expertise, linkage to external industries, or other factors, may be more closely matched to institutions that are otherwise quite dissimilar.

One approach that enhances the matching potential of content between institutions is to use categories based on identifiable characteristics where the differentiation is defendable. Institutional size, degrees offered, 
geographic proximity, and target student populations are all potential examples used for categorization. An example of university groupings used by a regional university could be as follows:

- $\quad$ Competing: Regional universities targeting a similar student population in the same specified geographical area as the university seeking accreditation or reaccreditation.

- Comparable: Regional universities that target a similar student population outside of the geography of the university seeking accreditation or reaccreditation.

- $\quad$ Aspiring: Nationally recognized universities.

The faculty team is responsible for deciding on a categorization guideline and the actual selection of the institutions that are included in the analysis. The team's diverse educational backgrounds and experiences are drawn upon to create a defendable external group of institutions for comparative purposes.

Obtaining curriculum content information from the selected institutions requires an extensive review of the catalog information each university provides. Business program data, including required courses for the degree and course descriptions related to content topics, need to be analyzed and documented. Team members can meet as needed to review the information collected and to find consensus where differences between members may exist regarding content matching. Occasionally, individual members may find it necessary to contact faculty or administrators at external institutions to clarify details of the publicly available information.

As the data are collected, analyzed, and interpreted, the team needs to create a data collection form for recording the findings for others to view. On this form, individual institutions are identified for every content standard where courses are linked to the content. This is also useful when benchmarking is used. An individual program can see how it compares and differs with other business programs in how, where, and the extent to which the content standards are covered. A comments category allows faculty team members the opportunity to record information of interest where such information is available for later consideration and analysis. Figure 2 is an example of a data collection form for capturing the needed information from other universities.

Communication Abilities - Regional Universities

\begin{tabular}{|l|l|l|l|l|}
\hline \multicolumn{1}{|c|}{ University } & Course Title & Course \# & Semester Hours & Comments \\
\hline University 1 & & & & \\
\hline University 2 & & & & \\
\hline University 3 & & & & \\
\hline University 4 & & & & \\
\hline University 5 & & & & \\
\hline
\end{tabular}

Figure 2. Form for Collecting External University Content

The example data collection form allows members of the faculty team to record information on external universities in a standardized systematic way. The completed forms allow for easy comparisons between information gathered by individual team members when the team convenes for discussions. The forms can be kept for documentation purposes, and inclusion in a final report for accreditation strengthens the process. This example form captures significant detail from other institutions and allows commentary on how the content matches with their university. This recording format helps each member to have available information for curriculum management purposes and underscores documentation support showing the external university review.

\section{External Constituent - Recent Alumni}

Retrieving information from recent alumni is critical in the analysis and review of curriculum. Creating a survey requesting information from graduates currently in the labor market is one approach to capturing needed data. The survey should be built around the content topics listed in Table 1 presented previously. Scaling content topics for respondents should measure perceived levels of preparation from very well prepared to unprepared. This information accesses recent graduates' view of how well the program prepared them across the topics. The survey 
can be offered in a paper format that is mailed or electronically, which saves time and postage. Appendix 1 contains an example survey used for collecting data from recent alumni.

Additional survey items may also be constructed to gather how each respondent views the importance of individual content topics in their careers. This information allows adjustments to curricula that better prepares students for the jobs they enter into following their undergraduate or graduate education. Fine tuning courses to enhance student success once they graduate is incorporated into the curriculum management process.

\section{External Constituent - Business Advisory Council}

Many business schools or colleges have a council of executives who have vested interests in the success of the program. These executives may include, but not be limited to, former graduates who have achieved substantial success in their careers. Sometimes these executives represent employers who hire graduates of the program and/or employ faculty as consultants or researchers. An advantage of having a Business Advisory Council is that they are customarily in successful career positions and understand what a curriculum should provide students leading to success. Additional benefits beyond input on curriculum include financial support. This support may indirectly help with curriculum where needed changes require financing beyond the resources currently available to the business program.

Collecting information from the council should follow a similar format as presented previously for recent alumni. A survey patterned on the content topics allows council members to provide input on what they perceive as most important in the business curriculum. This information can be analyzed and used for curriculum management changes and provides support for external validity purposes needed by AACSB. If the advisory council meets on campus for scheduled events, personal feedback in a focus group format can also be collected further supporting the curriculum management process.

\section{External Constituent - Employers}

Employers are another source of valuable information enhancing external validity of the business curriculum. Since this group is critically important to the success of the program, collecting information on their perceptions allows changes to course offerings that enhance both their businesses' success and the success of the graduates they hire.

A survey is again a convenient approach to collecting the needed data. The survey should be a refinement of what is used for the advisory council. Asking employers to respond to the importance of the content topics and to assess how prepared the business program's graduates are is extremely beneficial. Survey results can be sent physically by mail using employer contacts available from career service campus units. If electronic contacts are available, the survey can be deployed using the Internet. Employers frequently visit campus for career fairs where surveys may be distributed individually. If employers agree, focus group processes can also be used following career fairs. All information collected should be documented and saved for inclusion in the final report on curriculum management.

\section{THE FINAL REPORT}

The process of curriculum review is an ongoing activity where periodic reviews of everything previously presented is conducted. The faculty team is now in a position to review the current business program where improvements can be offered, supported, and implemented. The team makes decisions incorporating inputs from every source. Support for changing curriculum is based on the data collected and the processes used. All processes and information collected are incorporated into a report that can be shared with the various stakeholders. In addition, this report provides a well-documented, systematic process overview where AACSB accreditation teams can review what has been completed in terms of curricula management. 
This report, however, is not the final effort for curriculum management, but rather the foundation for future review and adjustment. Other accreditation processes, especially those incorporated in the "Assurance of Learning" category, now have the data to support their individual processes with curriculum that can be defended both internally and externally. Without the pillar of excellent curriculum, AACSB accreditation will not take place.

\section{SUMMARY AND CONCLUSIONS}

Receiving accreditation from The Association to Advance Collegiate Schools of Business establishes the external validation of quality that external constituents demand. The effects of accreditation also have consequences for internal groups including students, faculty, and administrators. Students in AACSB accredited institutions know that they are receiving a leading edge education that makes them more competitive in the marketplace. This competitiveness manifests itself in improved job hunting prospects including starting remuneration. Faculty can be confident in their educational endeavors knowing that what they do is accepted by external groups as value added. Additionally, faculty in AACSB accredited schools have been shown to earn more than faculty in non-accredited programs (Hedrick et al., 2010). Administration benefits from accreditation in being able to market its business program as high quality as discussed previously. Including the quality endorsement that AACSB implies in marketing the business program helps to attract more and better students. Improved student recruiting provides a virtuous cycle where increasing enrollments result in increasing revenues for the institution. Recruiting higher quality students provides graduates who will progress and succeed faster in their careers. This also enhances the likelihood of increased endowments to the university where the success of former students parallels charitable giving.

Accreditation is not forthcoming with only acceptable curricula management. However, without success in managing curricula, accreditation is not possible. The processes described previously for curriculum management are not intended as a cookbook for gaining a key component for accreditation. The intention is to show how an institution can manage curriculum with the support of information from both internal and external sources. External sources ultimately determine the success of any business program, so it is logical that including their data in the process supports the validation of quality. Internal sources come from faculty who create and manage the process. Quality curriculum is the outcome of the process and is the pillar for other standards included in "Assurance of Learning." We are currently in the process of completing our next step: studying individual departmental curriculum and course assessments to determine strength of coverage of each cited item.

\section{AUTHOR BIOGRAPHIES}

David E. Gundersen is a Professor of Management at Stephen F. Austin State University. He received his Ph.D. from the University of Mississippi in 1992. His research specialties are in the human resource management area including compensation, performance appraisal, labor relations, and employee selection. He has published more than 50 refereed journal articles and conference proceedings during his tenure at Stephen F. Austin State University.

Susan Evans Jennings is a Professor of General Business at Stephen F. Austin State University. She currently teaches courses in business communication, business communication technologies, and information management. She holds a doctorate in Developmental Education-Instructional Systems and Technology with a cognate area of business in addition to a BSE and MEd in business education. Dr. Jennings has served as the editor of the Association for Business Communication- Southwest Proceedings and the Mountain-Plains Business Education Journal. She has authored two textbooks for Cengage and been the reviewer for numerous textbooks, journals, proceedings, and presentations.

Dr. Deborah Dunn is an Associate Professor of Computer Science at Stephen F. Austin State University. She received her Ph.D. from Texas A\&M University in 1995 and taught there and at Tusculum College before joining the faculty at SFA in 2002. She teaches primarily in the areas of programming and databases. Her research focus is on increasing interest in technology through robotics and programming and she is currently director of the summer camp and teacher workshop program at SFA. 
Dr. Warren W. Fisher is Professor of Management in the Department of Management, Marketing, and International Business at Stephen F. Austin State University (SFA). He received his $\mathrm{PhD}$ in Operations and Logistics Management from the University of Texas at Austin in 1983 and taught both there, at the University of Oklahoma, and at the University of Mississippi before joining the faculty at SFA in 1990. He teaches operations management, management information systems, and quantitative methods. Dr. Fisher's articles have been published in a variety of journals including Decision Sciences.

Dr. Mikhail S. Kouliavtsev is Associate Professor of Economics in the Department of Economics and Finance at Stephen F. Austin State University (SFA). He received his PhD in Economics from Temple University in 2003 and taught both there, and at Philadelphia University before joining the faculty at SFA in 2007 . He teaches macroeconomics, managerial economics, money and banking, and statistics. Dr. Kouliavtsev's articles have been published in a variety of academic journals including Economic Inquiry, Review of Industrial Organization, Empirical Economics, and Review of International Economics.

Dr. Violet C. Rogers is a Professor of Accountancy at Stephen F. Austin State University. She received her PhD from the University of North Texas in 1993 and joined the faculty at SFA in 1991. She teaches Auditing, Accounting Regulation, and Managerial Principals. Dr. Rogers' articles have been published in a variety of academic Journals.

\section{REFERENCES}

1. Athavale, M., David, R., \& Myring, M. (2008). The integrated business curriculum: An examination of perceptions and practices. Journal of Education for Business, 85(5), 295-302.

2. BestBizSchools.com. (n.d.). Learn more about AACSB and why it matters when choosing a business school. Retrieved January 20, 2011, from Best Biz Schools: http://www.bestbizschools.com/aacsbaccredited/

3. Bryant, M., \& Scherer, R. (2009, Spring). Developing an effective mentor-business school relationship in the AASCB initial accreditation process. American Journal of Business, 24(1), 7-14.

4. Cann, C. W., \& Brumagim, A. L. (2008, September/October). How project management tools aid in Association to Advance Collegiate Schools of Business (AACSB) international maintenance of accreditation. Journal of Education for Business, 31-39.

5. Hedrick, D. W., Henson, S. E., Krieg, J. M., \& Wassell, C. S. (2010). The effects of AACSB accreditation on faculty salaries and productivity. Journal of Education for Business, 85, 284-291.

6. $\quad$ Olian, J. D. (2007, September/October). One size does not fit all. BizEd, 32-36.

7. Romero, E. J. (2008). AACSB accreditation: Addressing faculty concerns. Academy of Management Learning \& Education, 7(2), 245-255.

8. Sampson, S., \& Betters-Reed, B. (2008, Fall). Assurance of learning and outcomes assessment: A case study of assessment of a marketing curriculum. Marketing Education Review, 18(3), 25-36.

9. Shao, L. P., \& Anderson, L. P. (2009). How important is business faculty service? Review of Business Research, 9(1), 165-172.

10. The Association to Advance Collegiate Schools of Business. (n.d.-a). Accreditation. Retrieved January 2011, from AACSB International: http://www.aacsb.edu/accreditation/accreditedmembers.asp

11. The Association to Advance Collegiate Schools of Business. (n.d.-b). Business Accreditation Standards. Retrieved January 2011, from AACSB International: http://www.aacsb.edu/accreditation/business/standards/

12. The Association to Advance Collegiate Schools of Business. (n.d.-c). Business Accreditation Standards. Retrieved January 2011, from AACSB International: http://www.aacsb.edu/accreditation/business/standards/aol/standard15.asp

13. Weldy, T. G., Spake, D. F., \& Sneath, J. Z. (2008). Challenges and best practices: Meeting AACSB and SACS requirements. The Journal of Academic Administration in Higher Education, 4(2), 15-22. 
Appendix 1

\section{Recent Alumni Business Curriculum Survey}

Please take a few minutes to fill out this survey. The College of Business welcomes your feedback and your answers will be kept confidential. Thank you for your participation.

Please indicate the type of organization that best describes your employment interest (or present job)?

\begin{tabular}{llllll}
$\bigcirc$ & Accounting Services & $\bigcirc$ & Entrepreneurship/Small Business & $\bigcirc$ & Manufacturing \\
$\bigcirc$ & Banking/Financial Services & $\bigcirc$ & Human Resources Support & $\bigcirc$ & Real Estate \\
$\bigcirc$ & Computer Services & $\bigcirc$ & Insurance & $\bigcirc$ & Retail Services \\
$\bigcirc$ & Consulting & $\bigcirc$ & Law Enforcement & $\bigcirc$ & Wholesale Distribution \\
$\bigcirc$ & Distribution & $\bigcirc$ & Legal Services & \\
$\bigcirc$ & Other (please specify) & & & \\
\cline { 2 - 4 } & & & & \\
\end{tabular}

Are you employed at the time of completing this survey?

$\mathrm{O}$ Yes

O No

In what year did you graduate?

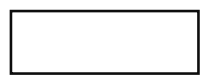

How satisfied are you with the education you received?
O
O
$\mathrm{O}$
O
$\bigcirc$

Very Satisfied

Satisfied

Dissatisfied Very Dissatisfied

In your perception, how important was an internship/work experience in getting hired?

O Very Important

Somewhat important

O Neutral

Somewhat unimportant

O Very unimportant

Not applicable - did not have an internship/work experience 
How well did the business program prepare you in the following knowledge areas?

\begin{tabular}{|c|c|c|c|c|c|}
\hline & $\begin{array}{l}\text { Very Well } \\
\text { Prepared }\end{array}$ & $\begin{array}{c}\text { Well } \\
\text { Prepared }\end{array}$ & Neutral & $\begin{array}{l}\text { Somewhat } \\
\text { Unprepared }\end{array}$ & $\begin{array}{c}\text { Totally } \\
\text { Unprepared }\end{array}$ \\
\hline Oral communication skills & ○ & ○ & $\bigcirc$ & $\bigcirc$ & ○ \\
\hline Written communication skills & O & O & O & O & O \\
\hline Interpersonal communication skills & O & O & O & O & O \\
\hline $\begin{array}{l}\text { Knowledge of fundamental information } \\
\text { technology skills and concepts }\end{array}$ & O & O & O & O & O \\
\hline Skills in identifying ethical issues in business & O & ○ & $\bigcirc$ & $\bigcirc$ & ○ \\
\hline Skills in ethical decision making & $\bigcirc$ & ○ & $\bigcirc$ & $\bigcirc$ & $\bigcirc$ \\
\hline $\begin{array}{l}\text { Skills in legal decision making in organizations } \\
\text { and society }\end{array}$ & O & O & O & O & O \\
\hline Reflective thinking skills & $\bigcirc$ & $\bigcirc$ & $\bigcirc$ & $\bigcirc$ & $\bigcirc$ \\
\hline Problem solving abilities & $\bigcirc$ & $\bigcirc$ & $\bigcirc$ & $\bigcirc$ & $\bigcirc$ \\
\hline Multicultural and diversity awareness & ○ & $\bigcirc$ & $\bigcirc$ & $\bigcirc$ & $\bigcirc$ \\
\hline Team skills & $\bigcirc$ & $\bigcirc$ & $\bigcirc$ & $\bigcirc$ & $\bigcirc$ \\
\hline Business knowledge and skills & ○ & O & ○ & $\bigcirc$ & ○ \\
\hline International (global) business awareness & $\bigcirc$ & $\bigcirc$ & $\bigcirc$ & $\bigcirc$ & $\bigcirc$ \\
\hline $\begin{array}{l}\text { Information technologies as they influence } \\
\text { structure and process of organizations }\end{array}$ & O & O & O & O & O \\
\hline Analytical skills & ○ & O & ○ & $\bigcirc$ & ○ \\
\hline Financial theories, analysis, reporting, and markets & $\bigcirc$ & $\bigcirc$ & $\bigcirc$ & $\bigcirc$ & $\bigcirc$ \\
\hline $\begin{array}{l}\text { Understanding of integrated production and } \\
\text { distribution of goods, services, and information }\end{array}$ & O & O & O & O & O \\
\hline Group and individual dynamics in organizations & O & O & O & O & O \\
\hline Statistical data analysis and management science & 0 & 0 & 0 & 0 & 0 \\
\hline
\end{tabular}

